\title{
Developing and evaluating clinical leadership interventions for frontline healthcare providers: a review of the literature
}

Solange Mianda* (i) and Anna Voce

\begin{abstract}
Background: The importance of clinical leadership in ensuring high quality patient care is emphasized in health systems worldwide. Of particular concern are the high costs to health systems related to clinical litigation settlements. To avoid further cost, healthcare systems particularly in High-Income Countries invest significantly in interventions to develop clinical leadership among frontline healthcare workers at the point of care. In LowIncome Countries however, clinical leadership development is not well established. This review of the literature was conducted towards identifying a model to inform clinical leadership development interventions among frontline healthcare providers, particularly for improved maternal and newborn care.
\end{abstract}

Methods: A structural literature review method was used, articles published between 2004 and 2017 were identified from search engines (Google Scholar and EBSCOhost). Additionally, electronic databases (CINHAL, PubMed, Medline, Academic Search Complete, Health Source: Consumer, Health Source: Nursing/Academic, Science Direct and Ovid ${ }^{\circledR}$, electronic journals, and reference lists of retrieved published articles were also searched.

Results: Employing pre-selected criteria, 1675 citations were identified. After screening 50 potentially relevant full-text papers for eligibility, 24 papers were excluded because they did not report on developing and evaluating clinical leadership interventions for frontline healthcare providers, 2 papers did not have full text available. Twenty-four papers met the inclusion criteria for review. Interventions for clinical leadership development involved the development of clinical skills, leadership competencies, teamwork, the environment of care and patient care. Work-based learning with experiential teaching techniques is reported as the most effective, to ensure the clinical leadership development of frontline healthcare providers.

Conclusions: All studies reviewed arose in High-Income settings, demonstrating the need for studies on frontline clinical leadership development in Low-and Middle-Income settings. Clinical leadership development is an ongoing process and must target both novice and veteran frontline health care providers. The content of clinical leadership development interventions must encompass a holistic conceptualization of clinical leadership, and should use work-based learning, and team-based approaches, to improve clinical leadership competencies of frontline healthcare providers, and overall service delivery.

Keywords: Clinical leadership development, Clinical leadership evaluation, Frontline healthcare providers, Bedside

\footnotetext{
* Correspondence: solange.zoe60@gmail.com

Discipline of Public Health Medicine, Room 236, 2nd floor George Campbell

Building, School of Nursing and Public Health, College of Health Sciences,

University of KwaZulu-Natal, Durban, South Africa
}

(c) The Author(s). 2018 Open Access This article is distributed under the terms of the Creative Commons Attribution 4.0 International License (http://creativecommons.org/licenses/by/4.0/), which permits unrestricted use, distribution, and reproduction in any medium, provided you give appropriate credit to the original author(s) and the source, provide a link to the Creative Commons license, and indicate if changes were made. The Creative Commons Public Domain Dedication waiver (http://creativecommons.org/publicdomain/zero/1.0/) applies to the data made available in this article, unless otherwise stated. 


\section{Background}

Clinical leadership by frontline healthcare providers is a critical part of bedside care [1]. Clinical leadership is recommended for the potential impact on clinical practice and on the clinical care environment, and contributes to safe and quality patient care, and to job satisfaction and retention of frontline healthcare providers [1-6]. Frontline healthcare providers are well placed to identify work inefficiencies, motivate other members of the care team to act on patient care, and lead change initiatives to correct problems that arise in the clinical setting. Frontline healthcare providers can also identify inefficiencies related to organizational structures and work flows, and to poor policies and procedures for the delivery of optimal patient care [2, 5, 7-10]. Conversely, poor frontline clinical leadership in the clinical setting has been associated with adverse events and clinical litigation settlements, prompting many healthcare systems, particularly in High-Income Countries (HICs), to invest significantly in interventions that support clinical leadership development $[3,11]$.

However, in Low- and Middle-Income Countries (LMICs), clinical leadership development is not well established. As an example, in South African maternity services, maternal and perinatal deaths have been associated with deficiencies in frontline clinical leadership [12-18]. Albeit the need for clinical leadership development interventions has been identified, there is little evidence to support the planning, implementation and evaluation of such interventions, particularly among frontline healthcare providers, in LMICs [13-18].

Towards identifying a model to inform clinical leadership development among frontline healthcare providers in LMIC, including maternity services in South Africa, a literature review was conducted. The purpose of the literature review was to synthesize published evidence on frontline clinical leadership development and its evaluation and included multiple frontline-care contexts. A database was constructed to extract important dimensions of the clinical leadership development interventions. Further, to synthesize the reported findings on the evaluation of the effectiveness of clinical leadership interventions, Kirkpatrick's evaluation approach was used $[19,20]$. Kirkpatrick's approach to evaluation comprises four levels, presented as a sequence, and includes evaluating the:

(1) Reaction: what participants think and feel about the intervention

(2) Learning: the resulting increase in knowledge or skills, and changes in attitude

(3) Behaviour: change in practice because of the intervention

(4) Result: the final result that occurs as a result of the intervention (e.g. service delivery, or patient outcomes) $[19,20]$.
The findings of the literature review will contribute to the design and evaluation of interventions to improve clinical leadership at the bedside in LMICs generally, and in the maternity services of South Africa specifically.

\section{Methods}

Aim

The aim of the literature review was to describe the characteristics and the evaluation of clinical leadership development interventions targeting frontline healthcare providers.

\section{Design}

A structured approach, the systematic quantitative literature review method [21], was used to search and identify the literature, and extract information on interventions for clinical leadership development.

\section{Search methods}

The searches were conducted using Google Scholar and EBSCOhost search engines. Additionally, electronic databases including CINHAL, PubMed, Medline, Academic Search Complete, Health Sources: Nursing/Academic Edition, Science Direct and Ovid ${ }^{\oplus}$ ), were searched using the following keywords: 'clinical leadership', 'frontline leadership', 'nursing leadership', 'ward leadership', 'medical leadership', 'clinician leadership' in combination with: 'development,' 'programme', 'interventions', 'evaluation' and 'training'. A manual search was conducted to trace sources in the reference list of retrieved published articles.

\section{Eligibility criteria}

Inclusion criteria Papers meeting the following criteria were included for review: (1) original research published in peer-reviewed journals; (2) grey literature; (3) reporting the implementation or evaluation of interventions for clinical leadership development; (4) published in English between 2004 and 2017.

Exclusion criteria Papers exploring the implementation and/or the evaluation of interventions or approaches for the development of health service or organizational leadership, or development of senior healthcare leaders were excluded.

\section{Assessment of publications}

The database search generated 1600 records; grey literature (health services reports, research reports, theses, and dissertations) generated 75 records; of which 1558 were duplicate. On a review of abstracts 117 papers were excluded [related to developing or evaluating organizational or health services leadership]. On screening 50 potentially relevant full-text papers, 24 were excluded [did not report 
on developing or evaluating clinical leadership for frontline healthcare providers], and 2 [did not have full text available]. Twenty-four papers met the inclusion criteria and were captured in the database.

Figure 1 presents the search algorithm indicating the number of identified studies, included and excluded studies, and reasons for exclusion.

The quality of the studies reviewed was appraised using the Standards for Reporting Implementation Studies (StaRI) [22]. Against the StaRI criteria, the studies reporting the interventions and the evaluation of interventions for clinical leadership development did not provide adequate descriptions of the interventions themselves, of the methods used in implementing the interventions, and of the evaluation of the interventions. However, they included sound descriptions of the aims and the target groups for which the interventions were designed. Two studies provided sufficient descriptions of the intervention, the implementation and the evaluation in order to produce transferable findings [23, 24]. Overall, the studies included in this review were of poor quality. However, the shortcomings identified did not detract from the purpose of the present literature review.

\section{Constructing the database}

A database was constructed to summarise the studies identified for the review. The following information was captured in the database: the country where the intervention/ evaluation was implemented, the aim of the intervention/ evaluation, the target population for which the intervention was designed, the content areas of the intervention, the educational approach used, the educational techniques used, the time frame of the intervention, how the impact of intervention was measured, the outcomes and limitations of the intervention as reported in the papers.

\section{Results}

The aim of this literature review was to establish, from the published corpus, how clinical leadership was developed among frontline healthcare providers. Interventions for clinical leadership were summarized and synthesized. A total of 24 papers exploring the implementation and the evaluation of interventions for clinical leadership development met the inclusion criteria. The interventions are summarized below.

\section{Country where the intervention was implemented}

All interventions for clinical leadership development included in this review were implemented in High-Income Countries (HIC). Thirteen papers reported on studies conducted in the United Kingdom (UK) (England, Ireland and Scotland) [25-37] while six reported studies in Australia [23, 38-42] and three in the United States of America (USA) [24, 43, 44]. One study was conducted in Belgium [45] and one in Switzerland [46] (Table 1).

\section{Aims of the interventions}

The emphasis of most interventions was on developing clinical skills. Some interventions were designed to develop leadership competencies, to promote succession planning, to enhance the contribution of frontline healthcare providers to patient experiences, and to ensure quality and safe health services [23-31, 36, 37, 39-42, 44-46]

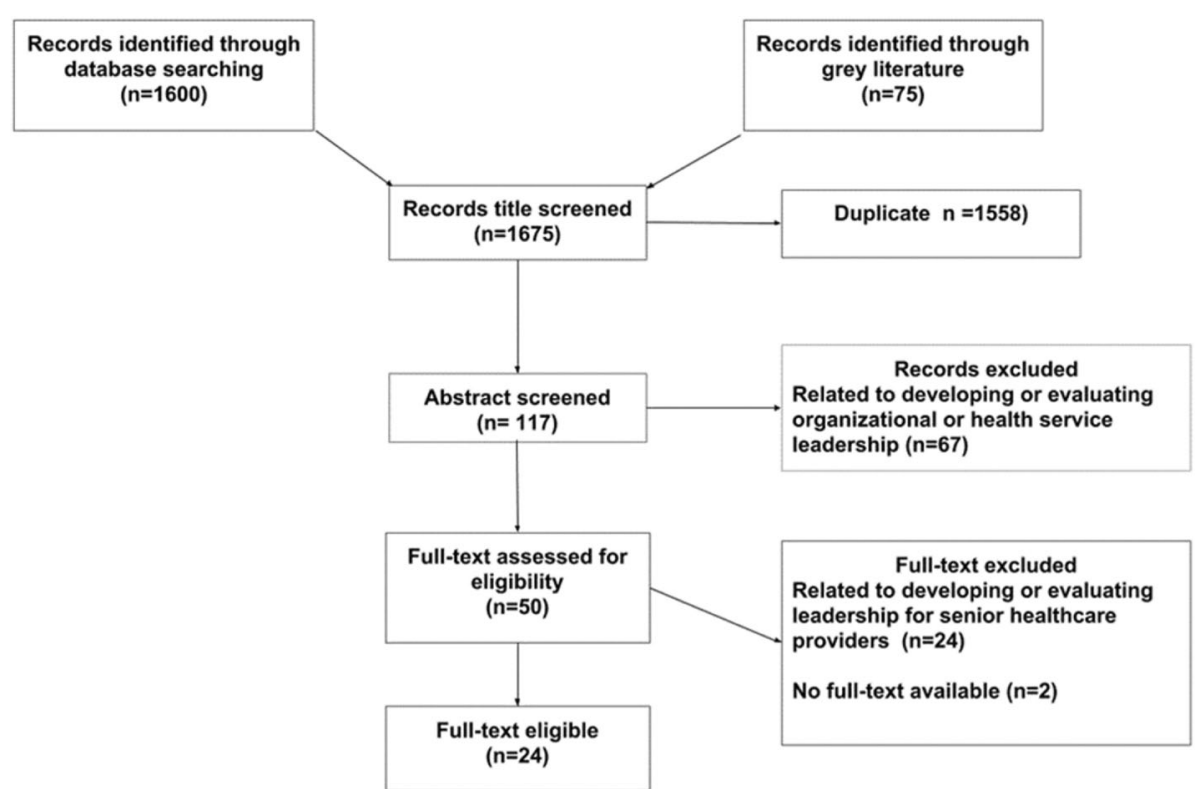

Fig. 1 Search algorithm, indicating number of identified studies, included and excluded studies, and reasons for exclusion 
Table 1 Country where the intervention was implemented

\begin{tabular}{|c|c|c|}
\hline Author & Country & Year \\
\hline Cleary et al. [38] & Australia & 2005 \\
\hline Ferguson et al. [39] & Australia & 2007 \\
\hline Williams et al. [40] & Australia & 2009 \\
\hline Travaglia et al. [41] & Australia & 2011 \\
\hline MacPhail et al. [23] & Australia & 2015 \\
\hline Leggat et al. [42] & Australia & 2016 \\
\hline Dierckx de Casterelé [45] & Belgium & 2008 \\
\hline Miller and Dalton [25] & England & 2011 \\
\hline Leeson and Millar [26] & England & 2013 \\
\hline Enterkin et al. [27] & England & 2013 \\
\hline Phillips and Byrne [31] & England & 2013 \\
\hline Castillo and James [32] & England & 2013 \\
\hline Stoll et al. [33] & England & 2011 \\
\hline Miani et al. [34] & England & 2013 \\
\hline Runnacle et al. [35] & England & 2013 \\
\hline Lunn et al. [28] & Ireland & 2008 \\
\hline McNamara et al. [29] & Ireland & 2014 \\
\hline Fealy et al. [36] & Ireland & 2015 \\
\hline Patton et al. [37] & Ireland & 2013 \\
\hline Pearson et al. [30] & Scotland & 2010 \\
\hline Martin et al. [46] & Switzerland & 2012 \\
\hline Kling [43] & USA & 2010 \\
\hline Abraham [44] & USA & 2011 \\
\hline Lekan et al. [24] & USA & 2011 \\
\hline
\end{tabular}

(Table 2). Other interventions focused on preparing nursing students, medical students, and novice frontline healthcare providers for future leadership roles and for ensuring quality care and patient safety $[33,35,43]$. Some interventions were developed to transform managers into leaders [32].

\section{Target group for which interventions were implemented}

Interventions for clinical leadership development targeted a variety of frontline health care providers (Table 3). Only a few interventions included frontline healthcare providers for maternal and child health [28-30, 32, 34, 36, 37, 41], while the remainder of interventions included early career nurses, qualified nurses, medical doctors, and allied healthcare professionals in hospital settings, including primary and secondary, acute, academic, community and regional hospitals, and mental health and geriatric wards [23, $26,27,31,35,38-40,44,45]$. Other target groups include novice students, senior level nursing students, senior registrars, and postgraduate medical and dental students [24, 25, 42, 43].

\section{Content areas covered by the interventions}

Development of clinical skills was common to the majority of interventions as summarized in Table 4 [24, 28, 30, 33, 35-39, 41-43, 45, 46]. Other content areas included personal development, teamwork, team management, team building, service delivery, care processes, and the environment of care needed to ensure quality and safe services [23, 26, 27, 29, 31, 32, 34, 40, 44].

\section{Educational approaches}

Primarily the interventions for clinical leadership development were offered in the form of in-service training using a work-based learning (WBL) educational approach within the clinical settings [28, 29, 31-34, 36-38, 42, 45, 46]. Classroom-based learning (CBL) conducted in classrooms outside of clinical settings $[30,43]$ or a combination of both were also used [27, $41,44]$. Some interventions were offered as postgraduate training programmes, using a combination of WBL and CBL [24, 25, 30, 35] (Table 5).

\section{Educational techniques}

Interventions for clinical leadership development targeting frontline healthcare providers made use of a variety of educational techniques, used singularly or in combination (Table 6.) A combination of action learning, mentorship and coaching was used in six interventions to develop various skills [28-30, 33, 36, 37]. Other educational approaches included inquiry-based learning, self-directed learning, case-based learning, problem-based learning, experiential learning, and shadowing [23, 25-27, 29, 31, 32, $35,38-40,42,44-46]$. Clinical supervision was used only in one intervention [24].

\section{Time frame of interventions for clinical leadership development}

Most interventions for clinical leadership development were offered as multiple contact sessions of varying duration, ranging from a few days, to a few weeks, or to lasting several months $[24,26,30,33,37-40,44-46]$ (Table 7). Other interventions were offered as multiple contact sessions in postgraduates programmes [24, 30, 35]. One intervention was offered as a full-time master degree programme with no detail of the contact sessions provided [25].

\section{How interventions were measured}

Best practice in measuring an intervention is to use pre-post evaluation. Nine out of twenty-four studies used pre-and post-test methods to measure the learning attainment, behaviour, and impact of the intervention 
Table 2 Aim of the intervention

\begin{tabular}{|c|c|c|c|}
\hline Author & Country & Year & Aim of the intervention \\
\hline Cleary et al. [38] & Australia & 2005 & Develop and consolidate clinical leadership skills \\
\hline Ferguson et al. [39] & Australia & 2007 & $\begin{array}{l}\text { Develop clinical leaders' skills to observe clinical practices } \\
\text { in a structured way to create a culture of quality and safety }\end{array}$ \\
\hline Williams et al. [40] & Australia & 2009 & Develop necessary skills to act as clinical leaders \\
\hline Travaglia et al. [41] & Australia & 2011 & Develop the skills to provide coordinated care \\
\hline MacPhail et al. [23] & Australia & 2015 & $\begin{array}{l}\text { Foster leadership capability and encourage engagement in } \\
\text { decision making within their teams }\end{array}$ \\
\hline Leggat et al. [42] & Australia & 2016 & $\begin{array}{l}\text { Develop clinical leadership skills in ensuring high quality and } \\
\text { safe health service }\end{array}$ \\
\hline Dierckx de Casterelé [45] & Belgium & 2008 & $\begin{array}{l}\text { Strengthen leadership competence in quality improvement } \\
\text { projects }\end{array}$ \\
\hline Miller and Dalton [25] & England & 2011 & Provide mentoring in clinical leadership \\
\hline Leeson and Millar [26] & England & 2013 & $\begin{array}{l}\text { Enable participants to take initiatives, focus on priorities and } \\
\text { continuous quality improvement }\end{array}$ \\
\hline Phillips and Byrne [31] & England & 2013 & $\begin{array}{l}\text { Enhance ward managers' contribution to patient experience } \\
\text { and quality of care }\end{array}$ \\
\hline Castillo and James [32] & England & 2013 & Transform managers into leaders \\
\hline Stoll et al. [33] & England & 2011 & Develop future clinical leaders \\
\hline Miani et al. [34] & England & 2013 & Foster a culture of quality improvement \\
\hline Runnacle et al. [35] & England & 2013 & Prepare trainees to ensure safe and effective services \\
\hline Enterkin et al. [27] & England & 2013 & Prepare participants for the role of ward sister \\
\hline Lunn et al. [28] & Ireland & 2008 & Develop transformational leadership behaviours \\
\hline McNamara et al. [29] & Ireland & 2014 & Develop clinical leadership skills \\
\hline Fealy et al. [36] & Ireland & 2015 & Develop leadership competence to improve service delivery \\
\hline Patton et al. [37] & Ireland & 2013 & Develop clinical leadership competencies \\
\hline Pearson et al. [30] & Scotland & 2010 & Develop leadership potential \\
\hline Martin et al. [46] & Switzerland & 2012 & Enhance leadership competence \\
\hline Kling [43] & USA & 2010 & Maximize students learning \\
\hline Abraham [44] & USA & 2011 & Enhance leadership skills \\
\hline Lekan et al. [24] & USA & 2011 & Support the development of clinical leadership \\
\hline
\end{tabular}

[23, 24, 28, 35, 38, 41, 42, 44, 46]. Fifteen studies used only post-test methods to measure the effectiveness of the interventions (Table 8).

To categorize how the different articles evaluated their interventions, Kirkpatrick's approach was used. Only one study included an evaluation at all four levels namely, the reaction, learning attainment and behaviour, and impact of the intervention on service delivery [32]. Measuring participant reactions to the interventions was common to most interventions [23-27, 29-32, 35, 38-40, 43]. Learning attainment, and the behavior of participants were also measured. The tools used to collect evaluation data included self-report questionnaires, online surveys, evaluation sheets, structured evaluation forms. Additional tools included in-depth-interviews, group interviews, FGDs, observations of action learning sets and document review.
Outcomes of the interventions as reported in the papers The outcomes of the interventions recorded in the papers include: personal development [increased self-awareness and confidence, feelings of empowerment, time management, development of emotional intelligence skills and increased learning ability] [27, 32, 34, 37, 38, 45]; enhanced leadership knowledge and skills [communication, willingness to lead teams, delegation, ability to empower others, problem solving, decision making, ability to inspire a shared vision, team management] [24, 26-29, 32, 34-37, 41, 43-46]; improved clinical knowledge and skills [enhanced basic nursing knowledge and skills, improved clinical practices, understanding of contribution to patient care] [42], improved teamwork [ability to work as part of multi-disciplinary teams, ability to manage teams] [23, 25, 30, 31, 37, 40, 43], improved patient care [increased focus on patient 
Table 3 Target group which interventions were implemented

\begin{tabular}{|c|c|c|c|}
\hline Author & Country & Year & Target group which interventions were implemented \\
\hline Cleary et al. [38] & Australia & 2005 & Mental health nurses \\
\hline Ferguson et al. [39] & Australia & 2007 & $\begin{array}{l}\text { Clinical leaders in mental and occupational health, } \\
\text { theatre, emergency, nursery, post-natal ward }\end{array}$ \\
\hline Williams et al. [40] & Australia & 2009 & New graduates (nurses) \\
\hline Travaglia et al. [41] & Australia & 2011 & Nursing and midwifery unit managers \\
\hline MacPhail et al. [23] & Australia & 2015 & Medical doctors, nurses and allied health professionals \\
\hline Leggat et al. [42] & Australia & 2016 & Medical doctors, nurses, and allied healthcare providers \\
\hline Dierckx de Casterelé [45] & Belgium & 2008 & Head nurses \\
\hline Miller and Dalton [25] & England & 2011 & Senior registrars \\
\hline Leeson and Millar [26] & England & 2013 & Nurses and allied healthcare professionals \\
\hline Enterkin et al. [27] & England & 2013 & Staff nurse and midwives, newly qualified nurses \\
\hline Phillips and Byrne [31] & England & 2013 & Ward managers \\
\hline Castillo and James [32] & England & 2013 & Wards managers, senior nurses and midwives \\
\hline Stoll et al. [33] & England & 2011 & Junior doctors \\
\hline Miani et al. [34] & England & 2013 & Doctors, nurses and midwives \\
\hline Runnacle et al. [35] & England & 2013 & Trainees doctors \\
\hline Lunn et al. [28] & Ireland & 2008 & Nurses and midwives \\
\hline McNamara et al. [29] & Ireland & & Nurses and midwives \\
\hline Fealy et al. [36] & Ireland & 2015 & Nurses and midwives \\
\hline Patton et al. [37] & Ireland & 2013 & Nurses and midwives \\
\hline Pearson et al. [30] & Scotland & 2010 & Early career and qualified nurses and midwives \\
\hline Martin et al. [46] & Switzerland & 2012 & Nurse leaders \\
\hline Kling [43] & USA & 2010 & Novice students \\
\hline Abraham [44] & USA & 2011 & Registered nurses \\
\hline Lekan et al. [24] & USA & 2011 & Senior level nursing students \\
\hline
\end{tabular}

care, improved patient outcomes], and service delivery [change in care processes] $[24,28,33,39,41,45]$ (Table 9).

\section{Limitations of the interventions}

Of studies that reported the limitations of interventions the following were identified: difficulty in gaining consent from patients to be observed while care was being provided and some trainers may not be skilled enough to observe using direct observation [39]; interventions that were too intensive and demanding, affecting the motivation and ability of participants to attend all sessions $[27,30,40]$; time away from clinical duties, resistance from colleagues to implement changed practices, and nurses or midwives taking clinical leadership roles and lack of support from health service managers [23, $25,34,41]$; short timeline for progamme implementation which did not allow for assessing the impact of interventions on participants, service users and on service delivery [23, 29, 34, 36]; and challenges with sustainability of gains made through the interventions [31, 38]. A lack of a control group in evaluating interventions was also considered a limitation in attributing changes to the intervention [24]. The transferability of the intervention was also questioned [42] (Table 10).

\section{Discussion}

This literature review of the implementation and evaluation of interventions for clinical leadership development was conducted towards identifying a model to inform clinical leadership development among frontline healthcare providers in Low- and Middle-Income Countries (LMICs) generally, and for the delivery of optimal maternal and perinatal care in South Africa specifically.

All descriptions of interventions for clinical leadership development derive from studies implemented in HICs. This would limit the transferability of study findings to LMICs, where clinical leadership is still underdeveloped and healthcare systems are faced with different contextual challenges [8]. Studies are required to explore appropriate interventions to improve clinical leadership in LMICs, including South Africa.

Of note, clinical leadership development programmes targeted novice to veteran frontline healthcare providers, 
Table 4 Content areas covered by the interventions

\begin{tabular}{|c|c|c|c|}
\hline Author & Country & Year & Content areas covered by the interventions \\
\hline Cleary et al. [38] & Australia & 2005 & Personal development, teamwork, clinical skills, service delivery \\
\hline Ferguson et al. [39] & Australia & 2007 & $\begin{array}{l}\text { Observation, feedback skills, clinical practice skills, patient care, } \\
\text { teamwork, environment of care, quality improvement (QI) }\end{array}$ \\
\hline Williams et al. [40] & Australia & 2009 & Leadership skills development \\
\hline Travaglia et al. [41] & Australia & 2011 & Clinical skills and leadership skills development \\
\hline MacPhail et al. [23] & Australia & 2015 & Leadership skills, multi-disciplinary teamwork \\
\hline Leggat et al. [42] & Australia & 2016 & Clinical skills leadership skills, quality and safety skills \\
\hline Dierckx de Casterelé [45] & Belgium & 2008 & $\begin{array}{l}\text { Clinical and leadership skills, teamwork, care environment, care } \\
\text { giving process }\end{array}$ \\
\hline Miller and Dalton [25] & England & 2011 & Teamwork \\
\hline Leeson and Millar [26] & England & 2013 & Leadership skills development \\
\hline Enterkin et al. [27] & England & 2013 & Leadership skills development \\
\hline Phillips and Byrne [31] & England & 2013 & Clinical skills development, teamwork and patient care \\
\hline Castillo and James [32] & England & 2013 & $\begin{array}{l}\text { Leadership skills development, team management, and service } \\
\text { improvement }\end{array}$ \\
\hline Stoll et al. [33] & England & 2011 & Personal development, clinical skills, service delivery \\
\hline Miani et al. [34] & England & 2013 & $\begin{array}{l}\text { Clinical skills and leadership skills, team management and the } \\
\text { environment of care }\end{array}$ \\
\hline Runnacle et al. [35] & England & 2013 & Clinical skills \\
\hline Lunn et al. [28] & Ireland & 2008 & Personal development, clinical skills, team building, patient care \\
\hline McNamara et al. [29] & Ireland & 2014 & Clinical leadership skills development \\
\hline Fealy et al. [36] & Ireland & 2015 & Clinical skills for service delivery \\
\hline Patton et al. [37] & Ireland & 2013 & Personal development and teamwork \\
\hline Pearson et al. [30] & Scotland & 2010 & Personal development, team management \\
\hline Martin et al. [46] & Switzerland & 2012 & Clinical and leadership practice \\
\hline Kling [43] & USA & 2010 & Clinical skills, personal development, leadership skills \\
\hline Abraham [44] & USA & 2011 & Leadership skills development \\
\hline Lekan et al. [24] & USA & 2011 & Leadership skills development, clinical skills, and patient care \\
\hline
\end{tabular}

in both formal and informal leadership positions [23]. This could indicate a previous neglect of ongoing clinical leadership development amongst frontline healthcare workers across the health system. With the emphasis on developing clinical expertise, interventions for clinical leadership development must include frontline healthcare workers who have been practicing for some time and may serve the purpose of updating veteran healthcare workers to new evidence-based practices of care.

Some interventions for clinical leadership development reported in this review embraced a holistic conceptualization of clinical leadership, paying attention to clinical skills, leadership skills, team building, team management, the environment of care, and service delivery $[34,38,45]$. Other interventions were more selective, based on checklists of whether participants manifested certain clinical skills. Interventions that embrace a holistic conceptualization of clinical leadership are more detailed, and can produce well trained and skilled clinical leaders. However, they may be expensive, and may require longer training periods, as they include multiple dimensions of clinical leadership. Interventions based on a selective understanding of clinical leadership may be shorter in nature, as they may focus on fewer dimensions of clinical leadership. However, these interventions may not be able to produce skilled clinical leaders.

Most interventions for clinical leadership development used work-based learning as an educational approach to improve, develop, maintain or increase practicing professionals' competence in the clinical setting $[47,48]$. Work-based learning (WBL) has been shown to promote practical learning and to help practitioners relate new knowledge to their work environment $[49,50]$. Classroom-based learning takes participants away from their work environment, a feature often considered as a major weakness of this approach $[49,50]$. A systematic review evaluating in-service training suggests that WBL is the most appropriate approach to improve not only the knowledge of participants but also the skills, behaviors and attitudes of participants [51-53]. WBL with 
Table 5 Educational approaches

\begin{tabular}{|c|c|c|c|}
\hline Author & Country & Year & Educational approaches \\
\hline Cleary et al. [38] & Australia & 2005 & Work-based learning (WBL) as in-service training \\
\hline Ferguson et al. [39] & Australia & 2007 & WBL as in-service training \\
\hline Williams et al. [40] & Australia & 2009 & WBL as in-service training \\
\hline Travaglia et al. [41] & Australia & 2011 & $\begin{array}{l}\text { Classroom based learning (CBL) as in-service training } \\
\text { with online interaction sessions }\end{array}$ \\
\hline MacPhail et al. [23] & Australia & 2015 & $\begin{array}{l}\text { WBL as in-service training and demonstration of } \\
\text { best practices }\end{array}$ \\
\hline Leggat et al. [42] & Australia & 2016 & WBL and Case-Based Learning as in-service training \\
\hline Dierckx de Casterelé [45] & Belgium & 2008 & WBL as in-service training \\
\hline Miller and Dalton [25] & England & 2011 & WBL as postgraduate programme \\
\hline Leeson and Millar [26] & England & 2013 & WBL as in-service training \\
\hline Enterkin et al. [27] & England & 2013 & WBL and $C B L$ as in-service training \\
\hline Phillips and Byrne [31] & England & 2013 & WBL as in-service training \\
\hline Castillo and James [32] & England & 2013 & WBL as in-service training \\
\hline Stoll et al. [33] & England & 2011 & WBL as in-service training \\
\hline Miani et al. [34] & England & 2013 & WBL \\
\hline Runnacle et al. [35] & England & 2013 & WBL postgraduate training \\
\hline Lunn et al. [28] & Ireland & 2008 & WBL as in-service training \\
\hline McNamara et al. [29] & Ireland & 2014 & WBL as in-service training \\
\hline Fealy et al. [36] & Ireland & 2015 & WBL as in-service training \\
\hline Patton et al. [37] & Ireland & 2013 & WBL as in-service training \\
\hline Pearson et al. [30] & Scotland & 2010 & CBL postgraduate programme \\
\hline Martin et al. [46] & Switzerland & 2012 & WBL as in-service training \\
\hline Kling [43] & USA & 2010 & CBL as in-service training \\
\hline Abraham [44] & USA & 2011 & WBL and $C B L$ as in-service training \\
\hline Lekan et al. [24] & USA & 2011 & WBL and CBL Postgraduate programme \\
\hline
\end{tabular}

experiential teaching techniques, such as mentoring and coaching, can ensure effective clinical leadership development of frontline healthcare providers.

In many interventions, the actual length of exposure to contact sessions, and the balance of time between the delivery of training content, and hands-on activities, were not detailed. The paucity of information poses a challenge when trying to replicate the interventions to other settings. In the interventions that did indeed describe the length of exposure to the intervention, multiple contact sessions, over varying periods of time, were used to deliver the interventions. Intensive once-off training sessions are shown to have a negative impact on participants' motivation [27, 40]. Multiple time-spaced contact sessions appear to be the most suitable approach to delivering in-service training programmes, as they provide participants with sufficient time and space to engage, reflect on the content of the training programme, and apply knowledge and skills to the work place $[52,54]$. While designing interventions for clinical leadership development, there is a need to ensure that a reasonable timeframe tailored to participants' needs is provided.

Most studies used only post-test evaluation to measure the effectiveness of the interventions. Post-test evaluation is outcome oriented and is concerned with the results of the intervention. The absence of pre-test observations and a lack of a control group in post-test evaluations limits the ability to attribute observed changes to the intervention [55]. Nonetheless, post-test is used in most interventions because of the logistical difficulties in obtaining pre-test observations due to time constraints [56].

Pre-post-test evaluation may be the most accurate way to provide a full picture of changes in participants over the course of the training programme. [56]. However, many interventions were implemented as once-off short interventions, over a couple of weeks. A short implementation timeline may not be sufficient to allow change to occur, and may not permit sufficient time to measure 
Table 6 Educational techniques

\begin{tabular}{|c|c|c|c|}
\hline Author & Country & Year & Educational techniques \\
\hline Cleary et al. [38] & Australia & 2005 & Self-directed, Learning (SDL) \\
\hline Ferguson et al. [39] & Australia & 2007 & Observation of clinical practice by clinical leaders, feedback and reflection \\
\hline Williams et al. [40] & Australia & 2009 & Mentoring and role modelling (unit managers to new nurses) \\
\hline Travaglia et al. [41] & Australia & 2011 & Coaching \\
\hline MacPhail et al. [23] & Australia & 2015 & SDL, Problem-based learning (PBL) \\
\hline Leggat et al. [42] & Australia & 2016 & Enquiry based learning (EBL), SDL \\
\hline Dierckx de Casterelé [45] & Belgium & 2008 & Action learning \\
\hline Miller and Dalton [25] & England & 2011 & Mentoring (senior managers to registrars) \\
\hline Leeson and Millar [26] & England & 2013 & PBL \\
\hline Enterkin et al. [27] & England & 2013 & SDL, Action learning \\
\hline Phillips and Byrne [31] & England & 2013 & $\mathrm{CBL}$, Action learning \\
\hline Castillo and James [32] & England & 2013 & Coaching Action learning \\
\hline Stoll et al. [33] & England & 2011 & Coaching, Mentoring Action learning, Ql projects \\
\hline Miani et al. [34] & England & 2013 & Experiential learning, QI projects \\
\hline Runnacle et al. [35] & England & 2013 & Experiential learning, QI projects \\
\hline Lunn et al. [28] & Ireland & 2008 & Experiential learning, Action learning, Coaching, Shadowing \\
\hline McNamara et al. [29] & Ireland & 2014 & Action learning Mentoring Coaching \\
\hline Fealy et al. [36] & Ireland & 2015 & SDL Mentoring Coaching Action learning \\
\hline Patton et al. [37] & Ireland & 2013 & SDL, Action Learning, Mentoring, Coaching \\
\hline Pearson et al. [30] & Scotland & 2010 & Coaching, Mentoring, Action learning sets \\
\hline Martin et al. [46] & Switzerland & 2012 & $\begin{array}{l}\text { Case Based Learning (CBL) } \\
\text { Coaching Action learning }\end{array}$ \\
\hline Kling [43] & USA & 2010 & Peer mentoring (senior students to novice students) \\
\hline Abraham [44] & USA & 2011 & Experiential learning \\
\hline Lekan et al. [24] & USA & 2011 & Bedside clinical teaching. Clinical supervision \\
\hline
\end{tabular}

the impact of interventions in participants, teams, environments of care, or service delivery [23, 30, 34, 36].

Kirkpatrick's approach to evaluation recommends four levels of evaluation to objectively measure the effectiveness of training programmes [19]. Most papers did not provide thorough descriptions of evaluation methods. Only one study reviewed included an evaluation at each of the four levels suggested by Kirkpatrick's approach [32]. Most papers reporting the evaluation of interventions for clinical leadership development focused on the reactions of participants and learning attainment [27, 32, 34, 37, 38, 45]. Participants reported positive experiences, and indicated the acquisition of leadership knowledge and skills as result of the intervention [27, 32, 34, 37, 38, 45]. Some studies reported improved clinical knowledge and skills improved teamwork as the behavior of participants $[23,25,29,33,34$, $40,42,43]$. The impact of interventions include improved patient care, improved patient outcomes, and change in care processes [24, 28, 33, 39, 41, 45].

Although some interventions used validated tools to evaluate the interventions, most outcomes recorded in this review used self-reported changes. Tools that elicit self-reported learning attainment and behaviour changes are considered to provide weak evaluation evidence and are of variable accuracy [57]. Factors that affect accuracy include information bias, influenced by recall bias and social desirability bias, and design bias, influenced by questionnaire design and mode of data collection [57]. To move beyond the weaknesses of to self-reported changes, the literature suggests the use of $360^{\circ}$ assessments [58-60]. This method involves an individual and several other people (e.g. peers, supervisors, assessors, and managers) provide a comprehensive feedback on an individual's behaviour and effectiveness [60]. It is suggested that used in combination with training programmes or interventions, $360^{\circ}$ feedback can be an effective assessment tool [58-60]. Adequate descriptions of interventions, and rigorous description of methods used in implementing, and evaluating the interventions are required to ensure transferability of findings of interventions to other settings.

Most studies did not discuss the limitations of the interventions, or the sustainability of gains made through 
Table 7 Time frame of interventions for clinical leadership development

\begin{tabular}{|c|c|c|c|}
\hline Author & Country & Year & Time frame of interventions for clinical leadership development \\
\hline Cleary et al. [38] & Australia & 2005 & 6 months (nature and length of contact sessions missing) \\
\hline Ferguson et al. [39] & Australia & 2007 & 12 observations over 4 months \\
\hline Williams et al. [40] & Australia & 2009 & 4 full time intensive weeks \\
\hline Travaglia et al. [41] & Australia & 2011 & $\begin{array}{l}5 \text { face-to-face days and monthly collaborative coaching over } \\
24 \text { months (length of coaching sessions missing) }\end{array}$ \\
\hline MacPhail et al. [23] & Australia & 2015 & One 2-h session once per month for 9 months \\
\hline Leggat et al. [42] & Australia & 2016 & 12 months (length of contact sessions \\
\hline Dierckx de Casterelé [45] & Belgium & 2008 & 12 months (nature and length of contact sessions missing) \\
\hline Miller and Dalton [25] & England & 2011 & $\begin{array}{l}\text { 1-year full time master's programme } \\
\text { (nature and length of contact sessions missing) }\end{array}$ \\
\hline Leeson and Millar [26] & England & 2013 & 2 days per week, every week over 6 weeks \\
\hline Enterkin et al. [27] & England & 2013 & 8 days, 1 day/ month over 8 months \\
\hline Phillips and Byrne [31] & England & 2013 & Four modules, each 8-h days per day \\
\hline Castillo and James [32] & England & 2013 & $\begin{array}{l}\text { Three } 1 \text {-day module, three } 1 / 2 \text { day action learning sets over } \\
8 \text { months }\end{array}$ \\
\hline Stoll et al. [33] & England & 2011 & $\begin{array}{l}12 \text { months full time programme (nature and length of contact } \\
\text { sessions missing) }\end{array}$ \\
\hline Miani et al. [34] & England & 2013 & $\begin{array}{l}2 \text { days (internal fellows), and } 4 \text { days a week external fellows) } \\
\text { over } 12 \text { months }\end{array}$ \\
\hline Runnacle et al. [35] & England & 2013 & $\begin{array}{l}\text { 1-h workshop; } 6 \text { months programme ( } 2 \text { full workshops } 1 \text { month } \\
\text { apart; over 1-year full time fellowship }\end{array}$ \\
\hline Lunn et al. [28] & Ireland & 2008 & 12 months (nature and length of contact sessions missing) \\
\hline McNamara et al. [29] & Ireland & 2014 & 6 months' (nature and length of contact sessions missing) \\
\hline Fealy et al. [36] & Ireland & 2015 & $\begin{array}{l}6 \text { months } \\
\text { tailored to participants needs }\end{array}$ \\
\hline Patton et al. [37] & Ireland & 2013 & Tailored to individuals' time frame over 6 months \\
\hline Pearson et al. [30] & Scotland & 2010 & $\begin{array}{l}1 \text { year flying start, } 2 \text { years masters' degree periodically, Action } \\
\text { learning sets, over three years }\end{array}$ \\
\hline Martin et al. [46] & Switzerland & 2012 & $\begin{array}{l}18 \text { days ( } 1 \text { day/month) over } 12 \text { months for the intervention } \\
\text { phase and over } 6 \text { months in the follow up phase }\end{array}$ \\
\hline Kling [43] & USA & 2010 & 3 h' classroom, 6 h per week clinical component \\
\hline Abraham [44] & USA & 2011 & $32 \mathrm{~h} /$ month over 6 months \\
\hline Lekan et al. [24] & USA & 2011 & $\begin{array}{l}3 \text { weeks SDL and CBL, } 3 \text { weeks } 8 \text { - h clinical rotation. 1-week } \\
\text { reflective journal }\end{array}$ \\
\hline
\end{tabular}

the intervention. One strategy to ensure sustainability of interventions for clinical leadership development is the team training approach [23]. A team training approach to clinical leadership development may serve a dual purpose: the transfer of skills and teambuilding. Teambuilding is an integral part of clinical leadership development, as well as an outcome of clinical leadership. A team training approach allows multiple professionals to be trained together, reduces resistance to change, and reduces the resistance to frontline healthcare leaders taking clinical leadership roles [23].

\section{Strengths of the review}

This review highlights the diversity, extent, and gaps of interventions for the development of clinical leadership among frontline healthcare providers. The review also highlights the conceptualizations of clinical leadership embedded in the interventions, and the challenges encountered in the implementation of interventions for clinical leadership development.

\section{Limitations of the review}

Although rigorous steps were carried out in this review, we are also aware of some limitations

- Studies may have been omitted from the review if they were not published in the databases searched, or if they were published in languages other than English. 
Table 8 How interventions were assessed

\begin{tabular}{|c|c|c|c|}
\hline Author & Country & Year & How interventions were assessed \\
\hline Cleary et al. [38] & Australia & 2005 & $\begin{array}{l}\text { Pre-and post-assessment to measure the reaction, and learning attainment } \\
\text { of participants using the Nurse Self-Concept Questionnaire }\end{array}$ \\
\hline Ferguson et al. [39] & Australia & 2007 & $\begin{array}{l}\text { Post-test to measure the learning attainment and behaviour of participants } \\
\text { using review of observation documents }\end{array}$ \\
\hline Williams et al. [40] & Australia & 2009 & $\begin{array}{l}\text { Post-test to measure the reaction participants using a Questionnaire and } \\
\text { focus group discussions (FDGs) }\end{array}$ \\
\hline Travaglia et al. [41] & Australia & 2011 & $\begin{array}{l}\text { Mid-term assessment to measure the learning attainment and behavior } \\
\text { of participants, and impact on service delivery interviews and online survey }\end{array}$ \\
\hline MacPhail et al. [23] & Australia & 2015 & $\begin{array}{l}\text { Pre-and post-assessment and follow-up } 18 \text { moths post intervention to assess } \\
\text { the reaction, and learning attainment of participants using structured } \\
\text { evaluation survey and questionnaire }\end{array}$ \\
\hline Leggat et al. [42] & Australia & 2016 & $\begin{array}{l}\text { Pre-and post-assessment to measure participants behaviour and impact of } \\
\text { the intervention using questionnaires and interviews }\end{array}$ \\
\hline Dierckx de Casterelé [45] & Belgium & 2008 & $\begin{array}{l}\text { Post-test assessment to measure the behaviour, learning attainment and } \\
\text { impact of the intervention, using interviews, FDGs and observation of } \\
\text { participants }\end{array}$ \\
\hline Miller and Dalton [25] & England & 2011 & $\begin{array}{l}\text { Post-test assessment to measure individuals' reaction using FDGs, interviews, } \\
\text { and online questionnaires }\end{array}$ \\
\hline Leeson and Millar [26] & England & 2013 & $\begin{array}{l}\text { Post-test assessment to measure the reaction and learning attainment, and } \\
\text { behaviour of participants, using evaluation sheets }\end{array}$ \\
\hline Enterkin et al. [27] & England & 2013 & $\begin{array}{l}\text { Post-test assessment to measure participants' reaction and learning } \\
\text { attainment questionnaires }\end{array}$ \\
\hline Phillips and Byrne [31] & England & 2013 & $\begin{array}{l}\text { Post-test assessment to measure the reaction and learning of participants, } \\
\text { using questionnaires }\end{array}$ \\
\hline Castillo and James [32] & England & 2013 & $\begin{array}{l}\text { Post-test assessment to measure participant reaction, learning, behaviour and } \\
\text { impact of the intervention using questionnaires }\end{array}$ \\
\hline Stoll et al. [33] & England & 2011 & $\begin{array}{l}\text { Post-test assessment to measure, learning attainment and impact of the } \\
\text { intervention, using questionnaires and interviews }\end{array}$ \\
\hline Miani et al. [34] & England & 2013 & $\begin{array}{l}\text { Post-test assessment to measure the learning of participant, behaviour, and } \\
\text { impact of the intervention, using Online questionnaires and interviews }\end{array}$ \\
\hline Runnacle et al. [35] & England & 2013 & Pre- and post- assessment to measure the reaction of participants \\
\hline Lunn et al. [28] & Ireland & 2008 & $\begin{array}{l}\text { Pre-and post-assessment to measure the reaction, learning and behaviour } \\
\text { of participants, using questionnaires }\end{array}$ \\
\hline McNamara et al. [29] & Ireland & 2014 & $\begin{array}{l}\text { Post-test assessment to measure participants' reactions using FDGs, and } \\
\text { interviews }\end{array}$ \\
\hline Fealy et al. [36] & Ireland & 2015 & $\begin{array}{l}\text { Post-test assessment to measure the impact of the intervention, using } \\
\text { service assessment tools }\end{array}$ \\
\hline Patton et al. [37] & Ireland & 2013 & $\begin{array}{l}\text { Post-test assessment to measure participants' learning and behaviour using } \\
\text { the leadership practice inventory, clinical leaders' behaviour questionnaires, } \\
\text { FGDs and group interviews }\end{array}$ \\
\hline Pearson et al. [30] & Scotland & 2010 & $\begin{array}{l}\text { Post-test assessment to measure participants' reaction and behaviour, using } \\
\text { FGDs and questionnaires }\end{array}$ \\
\hline Martin et al. [46] & Switzerland & 2012 & $\begin{array}{l}\text { Pre-and post-assessment to participants' behaviour using, observation and } \\
\text { self-assessment tools }\end{array}$ \\
\hline Kling [43] & USA & 2010 & $\begin{array}{l}\text { Post-test assessment at } 6 \text {-month post intervention to measure participant } \\
\text { reaction, learning attainment and behaviour using questionnaires }\end{array}$ \\
\hline Abraham [44] & USA & 2011 & $\begin{array}{l}\text { Pre-and post- assessment at } 6 \text { and } 12 \text { months following completion of } \\
\text { intervention to measure participant learning, behaviour and impact of } \\
\text { the intervention }\end{array}$ \\
\hline Lekan et al. [24] & USA & 2011 & $\begin{array}{l}\text { Pre-and post- test assessment to measure participant reaction, learning } \\
\text { attainment, and impact of the intervention }\end{array}$ \\
\hline
\end{tabular}


Table 9 Outcomes of the interventions as reported in the papers

\begin{tabular}{|c|c|c|c|}
\hline Author & Country & Year & Outcomes of the interventions as reported in the papers \\
\hline Cleary et al. [38] & Australia & 2005 & $\begin{array}{l}\text { Intervention useful to their work, } \\
\text { Improved communication, clinical skills, teamwork }\end{array}$ \\
\hline Ferguson et al. [39] & Australia & 2007 & $\begin{array}{l}\text { Opportunity to review care practices, development of QI plans, improved } \\
\text { observation and feedback skills, team building }\end{array}$ \\
\hline Williams et al. [40] & Australia & 2009 & Evaluated positively bay all stakeholders \\
\hline Travaglia et al. [41] & Australia & 2011 & $\begin{array}{l}\text { Feeling of empowerment to implement change in the work environment, } \\
\text { improved communication, unit performance and patient flow }\end{array}$ \\
\hline MacPhail et al. [23] & Australia & 2015 & $\begin{array}{l}\text { High satisfaction with the intervention, feasible, increased willingness to } \\
\text { lead teams and work as part of multidisciplinary teams }\end{array}$ \\
\hline Leggat et al. [42] & Australia & 2016 & $\begin{array}{l}\text { Improved leadership practices, emotional intelligence, psychological } \\
\text { empowerment patient safety skills }\end{array}$ \\
\hline Dierckx de Casterelé [45] & Belgium & 2008 & $\begin{array}{l}\text { Self-awareness enhanced communication skills, improvement of the work } \\
\text { environment }\end{array}$ \\
\hline Miller and Dalton [25] & England & 2011 & Successful in building teamwork and communication \\
\hline Leeson and Millar [26] & England & 2013 & $\begin{array}{l}\text { Positive experience, ability to take responsibility for action, change in } \\
\text { working practices }\end{array}$ \\
\hline Enterkin et al. [27] & England & 2013 & $\begin{array}{l}\text { Feelings of empowerment, self-awareness and confidence, ability to } \\
\text { delegate, and empower others, feeling of support from management }\end{array}$ \\
\hline Phillips and Byrne [31] & England & 2013 & Increased understanding of participants' contribution to patient care \\
\hline Castillo and James [32] & England & 2013 & $\begin{array}{l}\text { Improved confidence, better communication, increased problem-solving } \\
\text { skills }\end{array}$ \\
\hline Stoll et al. [33] & England & 2011 & $\begin{array}{l}\text { Greater understand of service delivery, change in care processes and } \\
\text { procedures }\end{array}$ \\
\hline Miani et al. [34] & England & 2013 & $\begin{array}{l}\text { Enhanced leadership and communication skills, team management skills, } \\
\text { increased confidence, improved patient experience }\end{array}$ \\
\hline Runnacle et al. [35] & England & 2013 & Improvement in use of quality improvement skills \\
\hline Lunn et al. [28] & Ireland & 2008 & $\begin{array}{l}\text { Enhanced communication, problem solving and decision-making skills, } \\
\text { ability to empower teams }\end{array}$ \\
\hline McNamara et al. [29] & Ireland & 2014 & Supportive and contributes to clinical leadership skills development \\
\hline Fealy et al. [36] & Ireland & 2015 & Service development, improved care practices \\
\hline Patton et al. [37] & Ireland & 2013 & Increased self-awareness, improved communication skills and team work \\
\hline Pearson et al. [30] & Scotland & 2010 & $\begin{array}{l}\text { Good in preparing participants for work challenges, increased ability to } \\
\text { manage relationships }\end{array}$ \\
\hline Martin et al. [46] & Switzerland & 2012 & Improved ability to inspire shared vision, and challenging the process \\
\hline Kling [43] & USA & 2010 & $\begin{array}{l}\text { Positive experience, enhanced basic nursing skills and knowledge, improved } \\
\text { time management and delegation skills }\end{array}$ \\
\hline Abraham [44] & USA & 2011 & Improved decision-making skills \\
\hline Lekan et al. [24] & USA & 2011 & $\begin{array}{l}\text { Improved communication skills, ability to delegate, skills to lead practice, } \\
\text { patient outcomes, promotion of nurses to supervisory posts }\end{array}$ \\
\hline
\end{tabular}

- The choice to limit the search to articles that described the implementation or evaluation of interventions for clinical leadership development among frontline healthcare providers, and published between 2004 and 2017, may have reduced the range of articles included in the review.

\section{Conclusions}

The literature review was conducted towards identifying a model to inform clinical leadership development among frontline healthcare providers in LMIC settings.
All studies reviewed arose in HIC settings, demonstrating the need for studies on frontline clinical leadership development in LMIC settings. The synthesis of studies conducted in HIC setting revealed what needs to be considered in the design of clinical leadership development interventions in LMIC settings. Firstly, clinical leadership development is an on-going process and must target both novice and veteran frontline health care providers. Secondly, the content of clinical leadership development interventions must encompass a holistic conceptualization of clinical leadership, with a 
Table 10 Limitations of the interventions

\begin{tabular}{|c|c|c|c|}
\hline Author & Country & Year & Limitations of the interventions \\
\hline Cleary et al. [38] & Australia & 2005 & Sustainability of the intervention is challenging \\
\hline Ferguson et al. [39] & Australia & 2007 & $\begin{array}{l}\text { Difficulty in gaining consent from patient to be observed; } \\
\text { skills of observer }\end{array}$ \\
\hline Williams et al. [40] & Australia & 2009 & $\begin{array}{l}\text { Too intensive thus affecting motivation and ability to attend } \\
\text { all sessions }\end{array}$ \\
\hline Travaglia et al. [41] & Australia & 2011 & $\begin{array}{l}\text { Resistance from colleagues to change, and nurse/ midwives } \\
\text { taking clinical leadership roles, time constraints }\end{array}$ \\
\hline MacPhail et al. [23] & Australia & 2015 & $\begin{array}{l}\text { Time away from clinical duties } \\
\text { Short timeline from progamme implementation and limited } \\
\text { evaluation of participants' leadership knowledge and skills }\end{array}$ \\
\hline Leggat et al. [42] & Australia & 2016 & * \\
\hline Dierckx de Casterelé[45] & Belgium & 2008 & * \\
\hline Miller and Dalton [25] & England & 2011 & Time away from the clinical setting \\
\hline Leeson and Millar [26] & England & 2013 & * \\
\hline Enterkin et al. [27] & England & 2013 & Intervention too long \\
\hline Phillips and Byrne [31] & England & 2013 & Maintaining momentum generated by the intervention \\
\hline Castillo and James [32] & England & 2013 & * \\
\hline Stoll et al. [33] & England & 2011 & * \\
\hline Miani et al. [34] & England & 2013 & $\begin{array}{l}\text { Resistance to change from frontline healthcare providers who } \\
\text { did not taking part in the programme. Short period of time to } \\
\text { enable change }\end{array}$ \\
\hline Runnacle et al. [35] & England & 2013 & * \\
\hline Lunn et al. [28] & Ireland & 2008 & * \\
\hline McNamara et al. [29] & Ireland & 2014 & * \\
\hline Fealy et al. [36] & Ireland & 2015 & * \\
\hline Patton et al. [37] & Ireland & 2013 & * \\
\hline Pearson et al. [30] & Scotland & 2010 & Intervention very demanding \\
\hline Martin et al. [46] & Switzerland & 2012 & \\
\hline Kling [43] & USA & 2010 & $*$ \\
\hline Abraham [44] & USA & 2011 & * \\
\hline Lekan et al. [24] & USA & 2011 & $\begin{array}{l}\text { Without control group changes cannot be conclusively } \\
\text { attributed to the intervention }\end{array}$ \\
\hline
\end{tabular}

*represents missing data

focus on clinical skills and on competencies that support optimal clinical care. Thirdly, interventions for clinical leadership development should use work-based learning approaches, and experiential and practice-based learning techniques, as these are more likely to contribute to the sustainable development of clinical leadership among frontline healthcare providers, and to the improvement in overall service delivery. Fourthly, team-based approaches to clinical leadership development, implemented through multiple contacts over a period of time, allow the acquisition and the transfer of skills, and teambuilding. Fifthly, assessment of the expected learning and evaluation of expected outcomes need to be carefully planned in the design of clinical leadership development interventions, and measured preferable through pre-post assessments, and $360^{\circ}$ assessments. Lastly, adequate description of the implementation setting, of the intervention model, and of the methods used in implementing and evaluating the interventions are necessary to ensure transferability of an intervention to other settings. These guidelines established from this review of the literature, must be incorporated in the design of interventions for clinical leadership development in LMIC settings.

\section{Abbreviations}

HICs: High-Income Countries; LMICs: Low-and-Middle-Income Countries; StaRl: Standards for Reporting Implementation Studies; UK: United Kingdom; USA: United States of America; WBL: Work based learning; CBL: Classroom based learning; SDL: self-directed learning; FGDs: focus group discussions

\section{Funding}

This paper is part of a Doctoral study partly funded through a scholarship from the College of Health Sciences at the University of KwaZulu-Natal. 


\section{Availability of data and materials}

All data generated or analyzed during this study are included in this published article.

\section{Author's contributions}

SM (University of KwaZulu-Natal) was the project leader involved throughout the study processes, from project design to write-up. AV (University of KwaZulu-Natal) is the first author's PhD supervisor who made conceptual contributions and provided technical guidance throughout the writing processes (revising the article). Both authors read and approved the final manuscript.

\section{Ethics approval and consent to participate}

Not applicable.

\section{Consent for publication}

Not applicable.

\section{Competing interests}

The authors declare that they have no competing interests.

\section{Publisher's Note}

Springer Nature remains neutral with regard to jurisdictional claims in published maps and institutional affiliations.

\section{Received: 27 April 2018 Accepted: 24 September 2018}

Published online: 01 October 2018

\section{References}

1. Abraham A. Care and compassion? Report of the Health Service Ombudsman on ten investigations into NHS care of older people. London; 2011. https://www.ombudsman.org.uk/sites/default/files/2016-10/ Care\%20and\%20Compassion.pdf.

2. Casey M, McNamara M, Fealy G, Geraghty R. Nurses' and midwives' clinical leadership development needs: a mixed methods study. J Adv Nurs. 2011; 67:1502-13.

3. Daly J, Jackson D, Mannix J, Davidson P, Hutchinson M. The importance of clinical leadership in the hospital setting. J Healthc Leadersh. 2014;6:75-83.

4. Edmonstone J. Evaluating clinical leadership: a case study. Leadersh Health Serv. 2009:22:210-24.

5. Grindel C. Clinical leadership: a call to action. Medsurg Nurs. 2016;25:9-16 http://www.ncbi.nlm.nih.gov/pubmed/27044123. Accessed 22 May 2017.

6. Supamanee T, Krairiksh M, Singhakhumfu L, Turale S. Preliminary clinical nursing leadership competency model: a qualitative study from Thailand. Nurs Health Sci. 2011;13:433-9. https://doi.org/10.1111/j.1442-2018.2011. 00649.x.

7. Doherty J. Leadership from 'below'? Clinical staff and public hospitals in South Africa | municipal services project. 2014. http://www. municipalservicesproject.org/publication/leadership-below-clinical-staff-andpublic-hospitals-south-africa. Accessed 22 May 2017.

8. Doherty J. Strengthening clinical leadership in hospitals: review of the international and south African literature. Municipal Service Project: South Africa; 2013.

9. Jonas S, McCay L, Keogh B. The importance of clinical leadership. In: Swanwick T, McKimm J, editors. ABC of clinical leadership. 1st ed. Oxford: Blackwell Publishing Ltd; 2011. p. 1-3.

10. Patrick A, Wong C, Finegan J, Laschinger HKS, Wong C, Finegan J, et al. Developing and testing a new measure of staff nurse clinical leadership: the clinical leadership survey. J Nurs Manag. 2011;19:449-60.

11. Wright L, Barnett P, Hendry C. Clinical leadership and clinical governance: a review of developments in New Zealand and internationally. New Zealand; 2001.

12. Schoon MG, Motlolometsi MW. Poor maternal outcomes: a factor of poor professional systems design. S Afr Med J. 2012;102:784. https://doi.org/10. 7196/SAMJ.6130.

13. Pattinson R, Rhoda N. Saving babies 2012-2013: ninth report on perinatal care in South Africa for the PPIP group. Pretoria: Tshepesa Press; 2014.

14. Pattinson R, Sithembiso V, Hardy B, Moran N, Wilhelm S. Overview. In: Pattinson R, editor. Saving babies 2006-2007 sixth report on perinatal care in South Africa. Pretoria; 2009. p. 1-39. http://www.ppip.co.za/wp-content/ uploads/Saving-babies-2006-7.pdf. Accessed 23 May 2017.
15. National Committee for the Confidential Enquiry into Maternal Deaths. Saving mothers 1998: confidential enquiry into maternal deaths in South Africa. In: Saving mothers. Pretoria; 1999.

16. National Committee for the Confidential Enquiry into Maternal Deaths. Saving mothers 2005-2007: fourth report on the confidential enquiry into maternal deaths in South Africa. In: Pretoria; 2008.

17. National Committee for the Confidential Enquiry into Maternal Deaths. Saving mothers 2011-2013: sixth report on the confidential enquiry into maternal deaths in South Africa. In: Pretoria; 2014.

18. Pattinson R, Tlebere P. Overview recommendations. In: Saving Babies 20032005: Fifth perinatal care survey of South Africa. 2007. p. 1-148.

19. Tian J, Atkinson NL, Portnoy B, Gold RS. A systematic review of evaluation in formal continuing medical education. J Contin Educ Heal Prof. 2007;27:1627. https://doi.org/10.1002/chp.89.

20. Kirkpatrick D. The four levels of evaluation. Info line, tips, tools, and intelligence for trainers. 3rd edition. American society for training and development: Pewaukeen; 2007.

21. Pickering C, Grignon J, Steven R, Guitart D, Byrne J. Publishing not perishing: how research students transition from novice to knowledgeable using systematic quantitative literature reviews. Stud High Educ. 2015;40:1756-69. https://doi.org/10.1080/03075079.2014.914907.

22. Pinnock H, Barwick M, Carpenter CR, Eldridge S, Grandes G. Standards for reporting implementation studies (StaRI): explanation and elaboration document. BMJ Open. 2017;7. http://digitalcommons.wustl.edu/open_ access_pubs. Accessed 8 Feb 2018.

23. MacPhail A, Young C, Ibrahim JE. Workplace-based clinical leadership training increases willingness to lead. Leadersh Health Serv. 2015;28:100-18. https://doi.org/10.1108/LHS-01-2014-0002.

24. Lekan DA, Corazzini KN, Gilliss CL, Bailey DE, Corazzini KN, Colón-Emeric C, et al. Clinical leadership development in accelerated baccalaureate nursing students: an education innovation. J Prof Nurs. 2011;27:202-14. https://doi. org/10.1016/j.profnurs.2011.03.002.

25. Miller S, Dalton K. Learning from an evaluation of Kent, Surrey and Sussex Deanery's clinical leadership fellowship programme. Int J Clin Leadersh. http://eds.a.ebscohost.com/eds/detail/detail?vid=0\&sid=a8955600-f640-43449fcc-d6150ec4bfa3\%40sdc-v-sessmgr02\&bdata=JnNpdGU9ZWRzLWxpdmU\% $3 d \# A N=61952376 \& d b=a 9 h$.

26. Leeson D, Millar M. Using the 7 habits programme to develop effective leadership. Nurs Manag. 2013;20:31-7 http://journals.rcni.com/doi/pdfplus/ 10.7748/nm2013.10.20.6.31.e1123. Accessed 23 May 2017.

27. Enterkin J, Robb E, McLaren S. Clinical leadership for high-quality care: developing future ward leaders. J Nurs Manag. 2013;21:206-16. https://doi. org/10.1111/j.1365-2834.2012.01408.x.

28. Lunn C, Mac Curtain S, Mac Mahon J. Clinical leadership pilot: evaluation report. Nursing \& Midwifery Planning \& Development Unit HSE West; 2008. http://www.lenus.ie/hse/handle/10147/312631. Accessed 22 May 2017

29. McNamara MS, Fealy GM, Casey M, O'Connor T, Patton D, Doyle L, et al. Mentoring, coaching and action learning: interventions in a national clinical leadership development programme. J Clin Nurs. 2014;23:2533-41. https:// doi.org/10.1111/jocn.12461.

30. Pearson P, Machin A, Rae A. Clinical leadership for the future: evaluation of the early clinical careers fellowship pilot programme. Scotland; 2010. http:// www.nes.scot.nhs.uk/media/308771/pauline_pearson_presentation_june_ 2010.pdf. Accessed 22 May 2017.

31. Phillips N, Byrne G. Enhancing frontline clinical leadership in an acute hospital trust. J Clin Nurs. 2013;22:2625-35. https://doi.org/10.1111/jocn.12088.

32. Castillo C, James S. How to turn ward managers into leaders. Nurs Times. 2013;109:18-9 http://www.ncbi.nlm.nih.gov/pubmed/23550485. Accessed 22 May 2017.

33. Stoll L, Swanwick T, Foster-Turner J, Foster-Turner J, Moss F. Leadership development for junior doctors. Int J Leadersh Public Serv. 2011;7:233-86. https://doi.org/10.1108/17479881111194161

34. Miani C, Marjanovic S, Morgan M, Marshal M, Meikle S, Notle E. Barking, Havering and Redbridge University hospitals NHS trust fellowships in clinical leadership Programme an evaluation. London; 2013. http://www.rand.org/ content/dam/rand/pubs/research_reports/RR300/RR367/RAND_RR367.pdf. Accessed 22 May 2017.

35. Runnacles J, Moult B, Lachman P. Developing future clinical leaders for quality improvement: experience from a London children's hospital. BMJ Qual Saf. 2013;22:956-63. https://doi.org/10.1136/bmjqs-2012-001718. 
36. Fealy GM, McNamara MS, Casey M, O'Connor T, Patton D, Doyle $L$, et al. Service impact of a national clinical leadership development programme: findings from a qualitative study. J Nurs Manag. 2015;23:324-32. https://doi. org/10.1111/jonm.12133.

37. Patton D, Fealy G, Mcnamara M, Casey M, Connor T, Doyle L, et al. Individual-level outcomes from a national clinical leadership development programme. Contemp Nurse. 2013;45:56-63. https://doi.org/10.5172/conu. 2013.45.1.56

38. Cleary M, Freeman A, Sharrock $L$. The development, implementation, and evaluation of a clinical leadership programme for mental health nurses. Issues Ment Health Nurs. 2005;26:827-42. https://doi.org/10.1080/ 01612840500184277.

39. Ferguson L, Calvert J, Davie M, Fallon M, Fred N, Gersbach V, et al. Clinical leadership: using observations of care to focus risk management and quality improvement activities in the clinical setting. Contemp Nurse. 2007;24:21224. https://doi.org/10.5555/conu.2007.24.2.212.

40. Williams AK, Parker VT, Milson-Hawke S, Cairney K, Peek C. Preparing clinical nurse leaders in a regional Australian teaching hospital. J Contin Educ Nurs. 2009:40:571-6. https://doi.org/10.3928/00220124-20091119-04.

41. Travaglia J, Debono D, Erez-Rein N, Milne J, Plumb J, Wiley J, et al. Report of the mid-program evaluation of "take the lead" Centre for Clinical Governance Research Australian Institute of health innovation. New South Wales; 2011. http://www.med.unsw.edu.au/medweb.nsf/page/ClinGov_ About. Accessed 23 May 2017.

42. Leggat SG, Smyth A, Balding C, McAlpine I. Equipping clinical leaders for system and service improvements in quality and safety: an Australian experience. Aust N Z J Public Health. 2016;40:138-43. https://doi.org/10. 1111/1753-6405.12462

43. Kling VG. Clinical leadership project. J Nurs Educ. 2010;49:640-3. https://doi. org/10.3928/01484834-20100831-02

44. Abraham PJ. Developing nurse leaders. Nurs Adm Q. 2011;35:306-12.

45. Dierckx de Casterle B, Willemse A, Verschueren M, Milisen K. Impact of clinical leadership development on the clinical leader, nursing team and care-giving process: a case study. J Nurs Manag. 2008;16:753-63. https://doi. org/10.1111/j.1365-2834.2008.00930.x.

46. Martin JS, McCormack B, Fitzsimons D, Spirig R. Evaluation of a clinical leadership programme for nurse leaders. J Nurs Manag. 2012;20:72-80. https://doi.org/10.1111/j.1365-2834.2011.01271.x.

47. Crofts J, Ellis D, Draycott T, Winter C, Hunt L, Akande V. Change in knowledge of midwives and obstetricians following obstetric emergency training: a randomised controlled trial of local hospital, simulation Centre and teamwork training. BJOG An Int J Obstet Gynaecol. 2007;114:1534-41. https://doi.org/10.1111/j.1471-0528.2007.01493.x.

48. Marinopoulos S, Dorman T, Ratanawongsa N, Wilson L, Ashar BH, Magaziner J, et al. Effectiveness of continuing medical education. Evid Rep Technol Assess (Full Rep). 2007:1-69 http://www.ncbi.nlm.nih.gov/pubmed/ 17764217. Accessed 22 May 2017

49. Cameron S, Rutherford I, Mountain K. Debating the use of work-based learning and interprofessional education in promoting collaborative practice in primary care: a discussion paper. Qual Prim Care. 2012;20:211-7 http:// primarycare.imedpub.com/debating-the-use-of-workbased-learning-andinterprofessional-education-in-promoting-collaborative-practice-in-primarycare-a-discussion-paper.php?aid=317. Accessed 22 May 2017.

50. Hardacre K, Schneider K. Work-based learning interim project report, overview of literature. PSE Consult Limited, People Ski Educ. 2007;5:1-35 https://www.heacademy.ac.uk/system/files/work_based_learning_literature_ review_30_october_07.pdf. Accessed 22 May 2017.

51. Coomarasamy A, Khan K. What is the evidence that postgraduate teaching in evidence based medicine changes anything? A systematic review. BMJ. 2004;329. https://www.ncbi.nlm.nih.gov/pubmed/15514348.

52. Bluestone J, Johnson P, Fullerton J, Carr C, Alderman J, BonTempo J, et al. Effective in-service training design and delivery: evidence from an integrative literature review. Hum Resour Health. 2013;11:51. https://doi.org/ 10.1186/1478-4491-11-51.

53. Raza A, Coomarasamy A, Khan KS. Best evidence continuous medical education. Arch Gynecol Obstet. 2009;280:683-7. https://doi.org/10.1007/ s00404-009-1128-7.

54. Kerfoot BP, Kearney MC, Connelly D, Ritchey ML. Interactive spaced education to assess and improve knowledge of clinical practice guidelines. Ann Surg. 2009;249:744-9. https://doi.org/10.1097/SLA.0b013e31819f6db8.
55. Shadish W, Cook T, Campbell D. Experiments and general causa inferences. In: Experiment and quasi-experimental designs for generalized causal inferences. New York; 2002. http://impact.cgiar.org/ pdf/147.pdf. Accessed 22 May 2017.

56. Schilling K, Applegate R. Best methods for evaluating educational impact: a comparison of the efficacy of commonly used measures of library instruction. J Med Libr Assoc. 2012;100:258-69. https://doi.org/10.3163/15365050.100.4.007.

57. Bhandari A, Wagner T. Self-reported utilization of health care services: improving measurement and accuracy. Med Care Res Rev. 2006;63:217-35. https://doi.org/10.1177/1077558705285298.

58. West M, Armit K, Loewenthal L, Eckert R, West T, Lee A. Leadership and Leadership Development in Health Care. London; 2015. https://www. kingsfund.org.uk/sites/files/kf/field/field_publication_file/leadershipleadership-development-health-care-feb-2015.pdf. Accessed 24 May 2017.

59. Kluger AN, DeNisi A. The effects of feedback interventions on performance: a historical review, a meta-analysis, and a preliminary feedback intervention theory. Psychol Bull. 1996;1 19:254-84. https://doi. org/10.1037/0033-2909.119.2.254.

60. Seifert CF, Yukl G, Mcdonald RA. Effects of multisource feedback and a feedback facilitator on the influence behavior of managers toward subordinates. J Appl Psychol. 2003;88:561-9. https://doi.org/10.1037/00219010.88.3.561.
Ready to submit your research? Choose BMC and benefit from:

- fast, convenient online submission

- thorough peer review by experienced researchers in your field

- rapid publication on acceptance

- support for research data, including large and complex data types

- gold Open Access which fosters wider collaboration and increased citations

- maximum visibility for your research: over $100 \mathrm{M}$ website views per year

At BMC, research is always in progress.

Learn more biomedcentral.com/submissions 